\title{
APPLYING CBR FOR DESIGN: Retrieval Phase
}

\author{
Nekrassov, G. \& Portuanski, L.
}

Abstract: For designing parts or assembly in CAD/CAM/CAE system many small enterprises use earlier designed alternatives of the similar designs and adapt these decisions of present cases. In the given paper the problems of realization CBR for designing parts and the implementation of this method into the educational process are considered. The structure of case storage (database and knowledge base) for general gadgets selected as an object for mining and sampling of the developed software are worked out. The software for selection of case from the database and record of new case are designed. As the database MS EXSEL is selected and VBAfor implementation the dialogue of a user interface with a system.

Key words: Case-Based Reasoning, integrated design environment, knowledge base
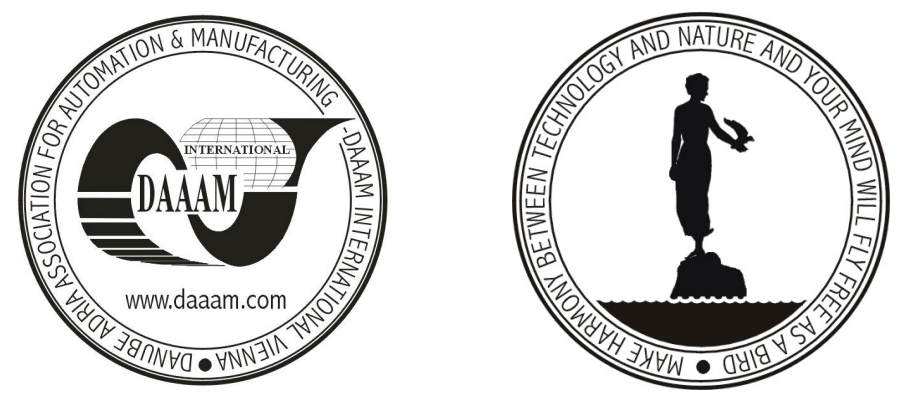

Authors' data: Ph.D. Eng. Nekrassov G.[rigori], Ph.D. Eng Portjanski L.[eonid], Department of Machinery, Tallinn University of Technology, Estonia, Grigori.Nekrassov@ttu.ee, Leonid.Portjanski@ttu.ee

This Publication has to be referred as: Nekrassov, G. \& Portjanski, L. (2006). Applying CBR for Design: Retrieval Phase, Chapter 35 in DAAAM International Scientific Book 2006, B. Katalinic (Ed.), Published by DAAAM International, ISBN 3-901509-47-X, ISSN 1726-9687, Vienna, Austria

DOI: $10.2507 /$ daaam.scibook.2006.35 